\title{
THE HISTORY OF POLISH PSYCHOTHERAPY DURING THE SOCIALIST DICTATORSHIP
}

(Received: 3 December 2007; accepted: 24 September 2008)

The paper presents the history of Polish psychotherapy from 1945 to 1989 . Psychotherapy was developed primarily within the framework of psychiatry, under the influence of trends present in the 'western' world, due to relatively active international scientific contacts and weak political and ideological limitations. Psychotherapists were instructed in different approaches. The equal rights and position of medical doctors and psychologists - members of the Polish Psychiatric Association Psychotherapy Section - and the domination of the scientific approach in psychotherapy were the Polish specificity. In 1989 the Certificate of Psychotherapist, confirming proper professional qualifications, was introduced.

Keywords: psychotherapy, Poland, communism, stage socialism, dictatorship, history, retrospect, helping profession, development, psychiatry

Geschichte der polnischen Psychotherapie während der sozialistischen Diktatur: Die Studie behandelt die Geschichte der polnischen Psychotherapie von 1945 bis 1989. Die Psychotherapie entwickelte sich, in erster Linie in dem von der Psychiatrie vorgegebenen Rahmen, dank der recht lebhaften internationalen wissenschaftlichen Kontakte sowie der geringen politischen und ideologischen Beschränkungen unter dem Einfluss der im Westen anerkannten Richtungen. Die Psychotherapeuten-Ausbildung vereinte mehrere unterschiedliche Herangehensweisen in sich. Eine polnische Besonderheit bestand darin, dass Ärzte und Psychologen über die gleichen Rechte und Positionen verfügten - beide waren Mitglieder in der Abteilung Psychotherapie der Polnischen Psychiatrischen Gesellschaft und hatten eine bestimmende Rolle bei der in der Psychotherapie angewandten wissenschaftlichen Herangehensweise inne. 1989 wurde die Qualifikation „Psychotherapeut“ als Nachweis für eine entsprechende fachliche Ausbildung eingeführt.

* Jerzy W. Aleksandrowicz, Department of Psychotherapy, The University Medical College in Kraków, ul. Lenartowicza 14, PL-31138 Kraków, Poland; mzaleksa@cyf-kr.edu.pl. 
Schlüsselbegriffe: Psychotherapie, Polen, Kommunismus, Staatssozialismus, Diktatur, Geschichte, Rückblick, helfender Beruf, Entwicklung, Psychiatrie

\section{The first decade after Word War II: Missing psychotherapists and the resurgence of psychotherapy}

World War II destroyed psychotherapy in Poland completely, even though it had not been very well developed before. Most psychiatrists (and in particular those with a psychoanalytic background) had either emigrated before 1939 or were killed by the Nazis. After 1945, there was practically no one able to reconstitute training of psychotherapists. So, the decade 1945-1955, the time of 'ideological war' with 'non-materialistic ideologies', did not have any particular impact on the development of practically non-existing psychotherapy.

The most important harm of that time was the belief that 'psychology is not a real field of science', which led to the temporary (ca. 3-year) closure of the psychological faculties at some universities for ideological reasons. The impact of ideological indoctrination on psychotherapy was very weak if any, perhaps because psychotherapy was perceived as a part of medicine. After a few years the tendency of political powers to ideologically influence the sciences weakened or even ended. The sociopolitical changes in October 1956 created some opportunities for intellectual and scientific development. This is what evidently distinguishes the situation in Poland from other countries of Eastern Europe. But the domination of the 'scientific point of view' and the non-acceptance of religion, as irrational unscientific speculation, persisted for many years. In that first post-war decade, psychiatry was nearly entirely oriented towards biology. However, some psychiatrists in different centers (coming mainly from social psychiatry and rehabilitation) developed their knowledge and skills in psychotherapy through self-education and international contacts. Marxist paradigms were (paradoxically?) helpful, the extensive promotion of Pavlovian psychophysiology was important support for the non-biological aspects of medicine.

Right after 1945, some institutions undertook the effort to reintroduce psychotherapy - e.g. the University Psychiatric Department and the Institute of Mental Hygiene in Warszawa (Warsaw). This institute led by Kazimierz Dąbrowski, one of the authors of the concept of 'positive disintegration' - the core of psychotherapeutic techniques employed here in the treatment of neurotic disorders - tried to develop many different approaches: psychoanalysis (Dr. Mazur), family and social counseling (Dr. Szymańska), etc. At the same time in the Psychiatric Clinic in Kraków (Krakow) Antoni Kępiński started professional development in a holistic direction, integrating biological, existential, and socio-cultural approaches, including psychotherapy. At this time, the practice of individual psychotherapy based on the dynamic and socalled 'rational-realistic' approaches was dominant. Some psychiatrists and psychologists were more oriented towards psychoanalysis, some towards the behavioral approach. 
Many doctors (not only in the academic departments and not only in psychiatry) introduced some elements of psychotherapy - such as autogenic training, relaxation, and hypnosis - into their practice. E.g. at the General Medicine Department of the University in Kraków, Julian Aleksandrowicz (hematologist!) developed a psychotherapeutic approach to internal medicine.

By the end of the 50s, the first institutions specialising in psychotherapy as a main or sole treatment method appeared. Jan Malewski (the psychoanalyst trained in Hungary) was a spiritus movens of psycho-dynamically oriented psychotherapy in Rasztów (near Warsaw). His collaborators were Michał Łapiński, Grażyna Malatyńska, Jerzy Pawlik and others. The theoretical background for this enterprise was provided by F. Knobloch and other colleagues from the Center for psychotherapy in Lobecz (Czechoslovakia). In 1958 Stefan Leder set up the Department of Neurotic Disorders at the Institute of Psychiatry and Neurology in Warszawa - which soon became the leading psychotherapeutic institution in Poland both in the practice and training and in research. An important Department of Neurotic Disorders was established in Poznań by Tadeusz Frąckowiak, another in Wrocław by H. Szydlik, and in Łódź by J. Goraj. Between 1956 and 1958, group psychotherapy was introduced by A. Kępiński and his collaborators at the Psychiatric Clinic of the Medical Academy in Kraków. It was dedicated mainly for psychotic patients or for groups that combined neurotic and psychotic patients (ALEKSANDROWICZ et al. 1974; ALEKSANDROWICZ \& CZABAŁA 1982; AleKSANDROWICZ 1983; LeDER et al. 1987; AleKSANDROWICZ \& SiWIAKKOBAYASHI 2002; BOMBA \& ALEKSANDROWICZ 2002).

\section{The emergence of a new generation and old controversies}

The consecutive decade (1956-1967) was a period of growing controversy between the strictly biological ('medical') school of psychiatry and the 'psychotherapeutic' (psychological) one. The excessive opinions stating that only soma or only psyche is involved in a medical disorder led to the point where many medical doctors increasingly stopped psychotherapy, and the development of medical centers was relatively weak. On the contrary, interest in psychotherapy among psychologists increased. The psychological faculties of the Universities of Warszawa, Kraków and Lublin introduced courses of basic psychotherapeutic concepts and techniques. This resulted in psychologists being much more numerous in the practice of psychotherapy than medical doctors. The most popular theories of psychotherapy were those of 'humanistic' approaches. Such an approach to psychotherapy was considered as something strange in the field of medicine (also by psychiatrists), and it was accepted (or sometimes only tolerated) only when practiced by psychologists, nurses, pedagogues and other 'supplementary staff members'. Acceptance of the holistic, bio-psycho-social approach, as a basis of psychotherapy acceptable for psychologists as well as for medical doctors, appeared a few years later. 


\section{The beginning of vigorous development}

At the end of that period, in 1960, the Polish Psychiatric Association (PPA) launched its Psychotherapy Scientific Section thanks to the joint efforts of T. Frąckowiak and $\mathrm{S}$. Leder. It changed the position of psychotherapy considerably. The Section, according to the rather unique general rules of the PPA, consisted of psychiatrists, doctors of other specialties as well as psychologists, pedagogues, etc. working in the Health Service. The Section became the hub of exchange of experience, training, and research in the field of psychotherapy for many years.

In the early 60s, new psychotherapy-oriented centers in Warsaw, Kraków and other cities (often in small villages like Rajsko, Moszna, or Dąbrówka) sprang up. In Kraków, the Chair of Psychiatry pioneered defining psychotherapy as a routine element of treatment in all subspecialised wards (Maria Orwid, Boguchwał Winid and others.) There was parallel development of both individual and group psychotherapy in different approaches and techniques, mainly psychoanalytical and behavioral. This growth of psychotherapy and differentiation of approaches was a consequence of the self-education in small groups of enthusiasts, as well as of the support of the informal international network of private professional contacts (ALEKSANDROWICZ et al. 1974; ALEKSANDROWICZ \& CZABAŁA 1982; ALEKSANDROWICZ 1983; LEDER et al. 1987; ALEKSANDROWICZ \& SiWIAK-KOBAYASHI 2002; BOMBA \& ALEKSANDROWICZ 2002).

Conflicts between different schools (e.g. psychoanalysis and behavioral approach) had a stimulating effect, even if sometimes they were destructive, as being steered more by narcissistic ambitions of some representatives than by rational reasons.

\section{International contacts}

Starting at this time, psychotherapists from Czechoslovakia and from Russia - mainly the Leningrad School of Psychiatry, exerted a considerable influence on the growth of psychotherapy in Poland. Particularly, the Czechoslovaks (J. Hausner, H. Junova, F. Knobloch, S. Kratochvil, and others) assisted largely in the training of Polish psychotherapists. Books by Stanislas Kratochvil were among the most popular and influencing manuals. Various theme-specific training programs had been conducted regularly - in psychodynamic psychotherapy, hypnosis, art-therapy, etc. Scholarships abroad (mainly England, France, and the United States) also played an important role in the development of psychotherapy. Since 1962 representatives of the Section regularly participated in international congresses, which included nearly all the IFMP and IAGP meetings.

Apart from psychoanalysis, concepts based on learning theory and existential and phenomenological approaches were also gaining ground. Therapeutic systems taking into account some specific Polish cultural and sociological aspects were also developed. 
But 1968-9 was a time of evident breakdown regarding international contacts as well as psychotherapy development. The growth of nationalism was harmful to all intellectual and professional activities. Although only very few psychotherapists of Jewish origin were among the thousands forced to leave the country, the socio-political situation inclined everybody to stay silent; it was not a time to express 'improper' humanistic ideas. Many psychotherapists were opposed to the contemporary 'official line' of the communist party.

\section{Development of psychotherapy in $1970-1980$}

\subsection{Scientific and training activities}

This time of restraint ended at the beginning of the seventies. The decade 1970-1980 was again a time of liberalisation and intensive growth for psychotherapy. The PPA Section of Psychotherapy organised national psychotherapy symposia (from 1974 at regular intervals) attended by foreign specialists, including leading therapists and researchers, such as: G. Ammon, A. Bergin, E. Brahler, J. Frank, V.E. Frankl, A. Heiberg, W. Hill, Ch. Kohler, O.H. Mowrer, C.G. Rogers and others. Thanks to these contacts, Polish psychotherapists were constantly brought up to date with the most recent trends and advances in psychotherapy worldwide.

In 1970 the first Polish psychotherapy journal was founded - edited by the PPA Section of Psychotherapy - at the beginning yearly, from 1972 quarterly. This journal published material consisting of both Polish reprints of important foreign papers and original papers by Polish psychotherapists (frequently bilingual - in Polish and in English). Also in 1970, several autonomous workgroups were established for psychotherapists, particularly engaged in psychoanalysis, behavioral therapy, hypnotherapy, group dynamics, psychodrama, music therapy, family therapy, transactional analysis, etc. and 12 regional groups of the Psychotherapy Section were also organised, helping in the mutual contacts and forming local psychotherapeutic milieus. At the same time the Section of Psychotherapy of Children and Adolescents of the Polish Society of Psychic Hygiene was founded.

The growth of interest in humanistic theories made them the dominant approach, not only in the Faculties of Psychology. Arguments were further fueled by a spreading belief that in the psychotherapist's activity, his or her personality - and not his or her clinical knowledge - was of primary importance, and this deeply influenced practice and concepts of psychotherapy training. Even though numerous psychiatrists were engaged in this stream, psychotherapy was still considered to be more psychological than the medical profession.

The efforts of the SP PPA in the 70s to reintroduce psychotherapeutic ideas and methods into medicine (in general, not only psychiatry) resulted in the rapid development of the Balint movement and in the introduction of psychotherapy as a compulsory element of every psychiatrist's training (the biggest formal success). Some new 
psychotherapy institutions appeared, like the Center for Psychotherapy of Personality Disorders and Personality Development, the 'Synapsis' Center and so on.

In the early 1970s, group psychotherapy became the form of psychotherapy most frequently applied in treating neuroses and personality disorders (ALEKSANDROWICZ 1983). The leading centers of those times - both in therapy itself as well as in training - were located in Warszawa and Kraków.

In the Department of Neurotic Disorders and Psychotherapy of the Institute of Psychiatry and Neurology an original eclectic program based on individual and group psychotherapy was developed (Stefan Leder, Czesław Czabała, Maria Siwiak-Kobayashi and others). Different techniques: art therapy - including individual and collective drawing and clay modeling, psychodrama, music therapy, choreotherapy (the original technique consists of a combination of dance and rhythm routines which enables treating mobility disturbances of neurotic patients), and occupational therapy with a leading component of the social-cognitive and behavioral orientations were used for the intensive therapy of neurotic and personality disorders. The basis of the psychotherapeutic system was a sound therapeutic community, which allowed the free flow of information, together with exercises in fulfilling various social roles. The research on psychotherapy processes and results started in this Department.

In Kraków, the Division of Psychotherapy was formed within the Department of Psychiatry (1975), and its Center for Treatment of Neurotic Disorders proposed an original, complex program based on psychotherapy in 'open' groups, of intensive treatment in day-hospitals (Jerzy W. Aleksandrowicz, Kazimierz Bierzyński and others). In 1985 the Department of Psychotherapy at the Psychiatric Clinic was established. This center also undertook research, mainly regarding the measurement of the effects of neurotic disorders psychotherapy. Nowadays, it is the independent Chair of Psychotherapy at the Jagiellonian University Medical College, and a separate psychotherapy course became a part of the obligatory curriculum for Jagiellonian University medical students. Such instruction of psychotherapy in the integrated training of mental health issues consecutively entered also into other medical faculties as a part of the undergraduate curriculum. So, psychotherapy developed intensively at this time. The particular characteristic of this development was cooperation and a general lack of hostile competition between the groups of psychologists and medical doctors, which was present in other countries.

In 1972 the Psychotherapy Section of the PPA started a training course of weekly classes based on the activity of T-groups. Its participants were exposed to psychotherapeutic techniques such as psychodrama, music therapy, pantomime, dance and art therapy, hypnosis activity therapy, etc. Not much later various other training programs in various specific areas of psychotherapy were organised.

The SP PPA was also one of the initiators of the common training and research network of the Eastern European Countries (Psychotherapy Socialist Countries' Workgroup) created in 1973, and organising congresses every 3 years (the first in Prague, 1973; then Warsaw, 1976; Leningrad, 1979, etc., the last in Sofia, 1988). This cooperation helped in the exchange of experiences and the promotion of new ideas in psychotherapy. In the 70s some psychotherapeutic books and manuals, written by Polish 
authors appeared, e.g. J. Malewski and M. Łapinski about neuroses and psychotherapy (MALEWSKI 1971), group psychotherapy (WARDASZKO-LYSKOWSKA 1973), psychotherapy in general practice (LEDER et al.1987) and others.

\subsection{Non-medical psychotherapy and anti-psychiatry}

At the same time the popularity of interpersonal and other types of training increased, replacing other forms of psychotherapy. Its use as a therapeutic modality in Poland became limited rather quickly, due to the frequent relatively rapid disenchantment, but it was used by various professional groups (sensitivity training) or as the way of integrating different groups, i.e. students. Different forms of 'therapy for healthy persons' were developed. Simultaneously, some forms of groups based on this approach started to be addressed towards specific patient populations. In many cities 'ex-patients' clubs for psychotic patients, for instance Alcoholics Anonymous groups and so on arose.

The mid-70s witnessed also the spread of views related to the anti-psychiatric trend. Numerous disputes were caused by the tendency to pay more attention to the development of patients' personalities while passing by the significance of their troubles. That trend reinforced the transformation of many psychiatric wards into therapeutic communities. This concept (introduced in the early 60s at the Psychiatric Clinics in Kraków, Warszawa and Poznań) started to be widely accepted in the 1970s by large psychiatric hospitals. In spite of this, the expression of overt hostility of antipsychiatric representatives to psychiatry and psychiatrists was one of the factors evoking some 'turn out' from the idea of community in psychiatric wards.

'Anti-psychiatry' also resulted in the growing discrepancy between psychotherapists oriented more towards the treatment of ill persons (mainly psychiatric patients) and those oriented more towards the spread application of psychotherapeutic concepts and techniques, aiming at facilitation processes leading 'a client' to be more spontaneous and promoting his or her self-realisation. The conflicts between 'medical' and 'psychological' psychotherapy were revealed. Those problems seriously stigmatised the development of psychotherapy in the subsequent decade (1980-1989).

\section{Development of psychotherapy at the time and after martial law}

At the beginning of this decade, Poland was the scene of many abrupt socio-political and economic changes. The ideology of the Solidarność movement was very close to the psychotherapists' view of the world, humanity and society. The martial law in 1981 was a difficult experience for the psychotherapeutic milieu, generally engaged in the Opposition. Some psychotherapists were arrested because of this; some of them emigrated from the country, due to both political and economic reasons. Even though the political authorities did not particularly oppress psychotherapy; the formal activity of associations was stopped. But those events did not substantially affect the activity 
of most Polish psychotherapeutic centers. Even at the time of martial law, the development of psychotherapy practice, training and research went on. The number of members of the PPA Psychotherapy Section grew successively and exceeded 500.

The practice offered particular experiences, e.g. the observation of the correlation between external tension in society and the 'unexpected' events in therapeutic communities, the necessity of solving problems of confidentiality and cooperation when some policemen and the Solidarność activists were treated in the same psychotherapy group, etc. On the other hand, in those days particular 'abuses of psychiatry' were relatively common - some activists of the Solidarność were diagnosed as 'psychiatrically ill' and admitted into psychiatric - also psychotherapeutic - wards, in order to offer them the opportunity to stay hidden.

During the second part of this decade, a number of particular modalities and techniques of psychotherapy, like psychodrama, music therapy, hypnosis, transactional analysis, Ericssonian therapy, or CBT started to be the area of interest. The intensive growth of engagement in systemic approach (M. Orwid, C. Czabała, B. de Barbaro, and others) was connected with the formation of the Family Therapy Section of the PPA. Particularly psychoanalysis, both in its format accepted by the IPA as in Lacanian and Jungian modifications was more and more popular. Several of those modalities had their representative working groups within the PPA Section of Psychotherapy being, in majority, members of respective international societies. Frequently those modalities evolved into new societies, independent from the PPA, providing training and in some cases also therapeutic services (Section of Psychotherapy in Association of Polish Psychologists, IPA Study Group, Gestalt, L'Ecole Freudienne, NLP and others). Some of them granted specific diplomas in psychotherapy. Psychosomatic medicine received its main formal body independent from the PPA - Section of Psychosomatic Medicine of the Polish Medical Association, and psychotherapy of addicts started to be the separated domain. Also the Catholic Church engaged in psychotherapeutic activity.

New books concerning psychotherapy and manuals about for instance analytical psychotherapy (PAWLIK 1981); Group Psychotherapy (LEDER \& KARWASARSKI 1983), family and marital therapy in substance abuse and other psychiatric disorders (ORWID \& CZABAŁA 1986) or neuroses - psychopathology and psychotherapy (ALEKSANDROWICZ 1988), as well as a general overview of psychotherapy (GRZESIUK 1994) appeared. They were helpful in the education of psychotherapists.

Openness to new approaches made it necessary to structure psychotherapeutic trainings that were invited to apply for the common PPA Psychotherapy and Family Therapy Sections accreditation. The first standard requirements were established, with the important help of the European Association of Psychotherapy. They included theoretical and skills training as well as personal experience and supervision of first psychotherapies. Different approaches were included in this training - psychodynamic, cognitive, Ericssonian, Jungian, integrative, etc. The sections of Psychotherapy and Family Therapy cooperated strictly witch the PPA Section of Child and Adolescent Psychiatry (Jacek Bomba, Irena Namysłowska, and Maria Orwid) in the development 
of psychotherapy. After some years of intensive preparations, in $1989^{1}$ the formal procedure of obtaining a Psychotherapeutic Certificate of the Polish Psychiatric Association was introduced, as well as the procedure of confirming qualification for supervision (Supervisor Certificate) (ALEKSANDROWICZ \& SIWIAK-KOBAYASHI 2002; BOMBA \& ALEKSANDROWICZ 2002).

\section{Summary}

The history of Polish psychotherapy in 1945-1989 was not seriously affected by the authoritarian dictatorship and therefore had relatively free, not ideological but scientific development, leading to both the professionalism (ca. 300 holders of a Certificate of Psychotherapist in 1991) and to the presence of different coexisting psychotherapeutic schools and modalities. Contrary to the past four decades, from the late $80 \mathrm{~s}$, the time of socio-political transformation, the impact of ideologies on the psychotherapeutic practice in Poland became much more significant. The role of different 'psychotherapeutic ideologies', theoretical approaches ('modalities') represented by the groups of psychotherapists engaged in competition in the training and in the practice, as well as the exigencies of subordination to those ideologies, was growing. It was connected also with the role of religion in social life and the general growing role of the beliefs and values. Like in the whole field of medicine (e.g. problems of abortion), in psychotherapy it also revealed different changes to the way of understanding patients' problems (e.g. conflicts between sexual needs and exigencies of the Church). The scientific approach to psychotherapy started to diminish. In contradiction to the orientation on the medical, mainly psychiatric issues, the point of view on psychotherapy as an independent profession arose. Also the practice of 'psychotherapists' lacking proper training and necessary competencies started to be frequent. These phenomena were the first signs of new serious problems in the development of psychotherapy, being of the greatest importance at the end of the $20^{\text {th }}$ and beginning of the $21^{\text {st }}$ century. But this is another story.

\section{References}

Aleksandrowicz, J.W. (1983) 'Group Psychotherapy in Poland' in H. KaPlan \& B. SADDOCK, eds. Comprehensive Group Psychotherapy (Baltimore \& London: Williams and Wilkins) 333-35.

AleKSANDROWICZ, J.W. (1988) Nerwice - psychopatologia i psychoterapia (Warszawa: PZWL).

Aleksandrowicz, J.W. \& C. Czabala (1982) 'Psychotherapy in Poland', The American Journal of Psychiatry 139, 1051-54.

\footnotetext{
${ }^{1}$ In some former publications mistakenly dated 1991.
} 
Aleksandrowicz, J.W \& M. SiWIAK-Kobayashi (2002) 'Psychotherapy in Poland' in A. BILIKIEWICZ \& J. RYBAKOWSKI, eds. Images in Psychiatry (Gdańsk: Via medica) 115-23.

Aleksandrowicz, J.W, C. Czabała, K. Czerniejewski, G. Malatyńska, H. SęK \& H. SzYDLIK (1974) 'Stan psychoterapii w Polsce', Abstr. I. Krajowe Symp. Psychoter Warszawa-Kraków, 17-30.

Bomba J, \& J.W. Aleksandrowicz (2002) 'Poland' in A. PriTz, ed. Globalized Psychotherapy (Vienna: Facultas UV) 227-34.

GrZESIUK, J., ed. (1994) Psychoterapia: Szkoły, zjawiska, techniki i specyficzne problemy (Warszawa: PWN).

LEDER, S. \& B. KARWASARSKI (1983) Psychoterapia grupowa (Warszawa: PZWL).

Leder, S., C. CZABAŁA, M. SiWIAK-KobAyAShi \& J.W. AleKsandrowicz (1987) 'Psychotherapy in Poland', Journal of Integrative and Eclectic Psychotherapy 6, 88-95.

MALEWSKI, J. (1971) Nerwice i Psychoterapia (Warszawa: Państwowy Zakład).

ORWID, M. \& C. CzABAŁA (1986) Terapia rodzin i malżeństw $w$ uzależnieniach i innych zaburzeniach psychicznych (Warszawa: PTP).

PAWLIK, J. (1981) Psychoterapia analityczna (Warszawa: PWN).

WARDASZKO-LYSKOWSKA, H., ed. (1973) Terapia grupowa w psychiatrii (Warszawa: PZWL). 